\title{
Performance Test of Zn HZSM-5/ $\gamma$-alumina catalyst in Biofuel Production from RBD Stearin as a Substitute for Fossil Fuels
}

\author{
Agus Budianto ${ }^{1}$, Sumari $^{2}$, Wahyu Setyo Pambudi ${ }^{3}$, Novi Andriani $^{4}$, A. Alif Mardianto ${ }^{5}$ \\ \{budichemical@itats.ac.id ${ }^{1}$ \} \\ Institut Teknologi Adhi Tama Surabaya, Indonesia ${ }^{1,3,4,5}$ \\ Universitas Negeri Malang, Indonesia ${ }^{2}$
}

\begin{abstract}
The use of renewable fuels is an alternative for the Indonesian government in addressing the problem of the energy conservation and environment. One of the keys to the success of the renewable fuel manufacturing process in the cracking method is the type and composition of the catalyst. This study conducted a performance test of $\mathrm{Zn}$ HZSM-5/ $\gamma$-alumina $(1: 1)$ and $(1: 2)$ catalysts for stearin cracking. The reaction test was carried out at 350 to $450{ }^{\circ} \mathrm{C}$ with an increase in temperature of $25{ }^{\circ} \mathrm{C}$. Stearin catalytic cracking was carried out in a fixed bed reactor that had been filled with catalysts. Stearin cracking results in a mixture of products in the vapor phase. The product was pushed and flowed through the condenser. In the condensation process a mixture of liquid and solid were produced. The liquid product was separated from the solid product, then its composition was analyzed using GC-MS. The results showed that the Zn-HZSM-5/ $\gamma$ alumina catalyst $(1: 1)$ and $(1: 2)$ can be used for cracking stearin to produce biofuels. Catalyst of Zn-HZSM-5/ $\gamma$-alumina $(1: 1)$ is better than Zn-HZSM-5/ $\gamma$-alumina $(1: 2)$ in producing products. The highest liquid yield of $26.40 \mathrm{wt} \%$ is obtained when the cracking process is carried out at $450^{\circ} \mathrm{C}$ using a catalyst of $\mathrm{Zn}-\mathrm{HZSM}-5 / \gamma$-alumina $(1: 1)$.
\end{abstract}

Keywords: Biofuel, Catalytic, Reactor, Stearin, Zn-HZSM-5, $\gamma$-alumina.

\section{Introduction}

HZSM-5 catalyst is an effective catalyst for the process of cracking $[1][2][3][4][5][6][7][8]$. HZSM-5 catalyst can be made from a mixture of certain chemicals by the Plank or Latourette method [3][5][7][9]. Catalysts such as natural zeolite rocks have been produced by some studies [10][11][12]. Catalyst of HZSM-5 and its derivatives are commonly used for cracking [1][8][13][14][15][16][17][18][19][20]. In addition, this catalyst can also be used to increase the production of glycerol [21]. Although the HZSM-5 catalyst has been shown to be able to cracking, this catalyst has weaknesses particularly the selectivity yield is still low [13].

The HZSM-5 catalyst's quality enhancement was performed to increase the yield of major products, material selectivity, acid tolerance, and high-temperature resistance. Several studies have made improvements by adding precious metals such as platinum and palladium [13], The use of Pt/HZSM-5 and Pd/HZSM-5 catalysts has improved product yields, but because the price of precious metals is very expensive, these catalysts have not been mass-produced. 
Additional studies try to combine cobalt and nickel to improve performance than HZSM-5 [3]. The use of Zn-HZSM-5 to improve the catalyst and has been shown to increase product yield, but this catalyst has a decrease in efficiency at high temperatures [8][22]. Zn-HZSM$5 / \gamma$-alumina catalyst is a two-catalyst combination that acts for cracking and has heat resistance as well. This catalyst has shown that it can be used to produce Calophyllum Inophyllum oil biofuels [18][22][23].

The successful use of Zn-HZSM-5/ $\gamma$-alumina catalysts to transform liquid plant oils into biofuels was very interesting although some biofuel raw materials in the form of solids are available. Stearin, Plastics and PFAD are one of the solid raw materials [14][24][25][27][28][29]. This fraction is less familiar with the general public, making it harder to sell [27]. Generally, solid fractions are harder to crack than that of fluid fractions. Therefore, a study to test Zn-HZSM-5/gamma Aluminum Catalyst for RBD Stearin cracking need to be conducted.

\section{Research Methods}

This study was conducted in the laboratory of renewable energy Institut Teknologi Adhi Tama Surabaya. The raw materials used were RBD stearin that available in Indonesian market, Zn-HZSM-5 and $\gamma$-alumina catalyst. As much as 1000 grams of RBD stearin were put in the reactor as shown in Figure 1. Ratio of Zn-HZSM-5 against $\gamma$ alumina catalyst $(1: 1)$ as much as 10 grams was included in the fixed bed reactor. The catalyst was hold by glass wool on the top and bottom of the fixed bed. The reactor was setup according to Figure 1. The reactor heater was then turned on and set at $350^{\circ} \mathrm{C}$ or according to the experimental variable. Stearin was evaporated when it reached that temperature. Stearin vapor flows to the top of the reactor and move through the catalyst, followed by cracking reactions. The combination of non-reacting materials and products will be pushed to the condenser. The cooling water tap on the condenser was opened to allow the cooling process to take place at the condenser. The liquid material mixture was collected in a container that was then analyzed using Gas Chromatography and Massa Spectrometer (GC-MS).

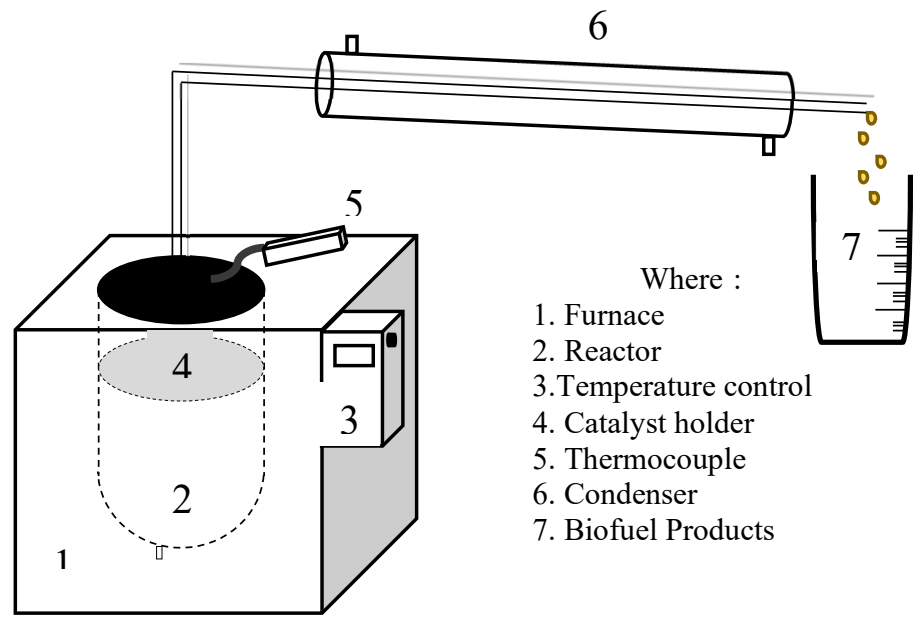

Fig. 1. Stearin RBD cracking device series using Zn-HZSM-5 catalyst $/ \gamma$-alumina. 


\section{Results and Discussion}

\subsection{The Effect of Temperature and Composition of Zn HZSM-5/ $\gamma$-alumina Catalysts on Biofuel yields produced}

Biofuel yields from cracking of RBD-Stearin using Zn-HZSM-5/ $\gamma$-alumina catalyst $(1: 1)$ and $(1: 2)$ at different temperatures can be seen in figure 2 . Liquid biofuel yield is one indicator of catalytic performance in the production of a liquid biofuel fraction. The results showed that an increase in temperature increases the yield of liquid biofuel. The results of this study are supported by other studies in which the higher the reaction temperature and reaction time the higher the yield in the catalytic cracking process [30]. The increase in the yield of liquid biofuel is due to the high-temperature catalysts activity that capable to break organic carbon chains of stearin and converted into biokerosen, biogasoline, and biodiesel fractions by releasing $\mathrm{CO} 2$ and $\mathrm{CO}$ gasses [14].

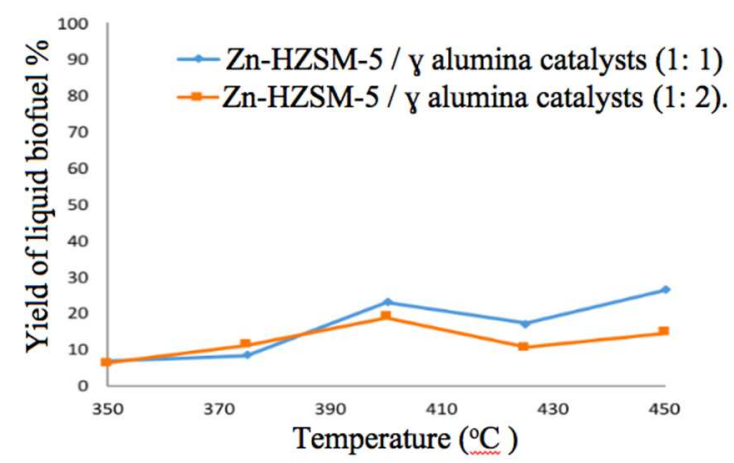

Fig. 2. Effect of temperature and catalyst ratio on the yield of liquid biofuel from RBD stearin using ZnHZSM-5 / $\gamma$-alumina catalysts $(1: 1)$ and $(1: 2)$.

The increasing of temperature at catalyst composition $(1: 1)$ from 350 to $400^{\circ} \mathrm{C}$ produce the liquid biofuel yield from $10 \%$ to $21 \%$. However, in the temperature range of 400 to $450{ }^{\circ} \mathrm{C}$ the yield decreases to $17.30 \%$. This is due to differences in catalyst activity in various temperature. The results of this study in line with the results of the synthesis of palm oil biofuel with the Au/HZSM-5 catalyst and its composites. The highest yield in the catalyst composition $(1: 1)$ was $26.40 \%$ at $450^{\circ} \mathrm{C}$ and the lowest yield was $6.70 \%$ at $350^{\circ} \mathrm{C}$. In the $(1: 2)$ catalyst composition the product yield of $18.90 \%$ obtained at the highest temperature of $450^{\circ} \mathrm{C}$ and the lowest yield of $6.30 \%$ obtained at $350^{\circ} \mathrm{C}$.

\subsection{Effect of Temperature and Composition of Zn HZSM-5/ $\gamma$-alumina Catalysts on Biofuel selectivity produced}

Biofuel compositions were analyzed using gas-spectroscopic chromatography or GC-MS to produce liquids such as $\mathrm{C} 6$ to $\mathrm{C} 30$ hydrocarbon atoms. A very wide range number of $\mathrm{C}$ atoms is difficult for classification. It can be overcome by dividing the number of $\mathrm{C}$ atoms into three main components, such as biogasoline, biokerosene, and biodiesel. The grouping of $\mathrm{C}$ atoms into three main components refers to Ortega who facilitate the classification, where 
biogasoline was a component with number of carbon $\mathrm{C} 6$ to $\mathrm{C} 11$, biokerosene with $\mathrm{C} 12$ to $\mathrm{C} 20$ number of carbon component and biodiesel with $\mathrm{C} 21$ to $\mathrm{C} 30$ carbon component [31].

Table 1. Results of biofuel selectivity with Zn-HZSM-5/ $\gamma$-alumina catalyst composition 1:1

\begin{tabular}{ccccc}
\hline \multirow{2}{*}{ No } & \multicolumn{4}{c}{ Selectivity \% } \\
\cline { 2 - 5 } & Temperature $\left({ }^{\mathbf{0}} \mathbf{C}\right)$ & Biogasoline & Biokerosene & Biodiesel \\
\hline 1 & 350 & 41.09 & 43.50 & 4.80 \\
2 & 375 & 32.85 & 60.18 & 6.08 \\
3 & 400 & 20.07 & 73.90 & 5.86 \\
4 & 425 & 14.52 & 75.94 & 9.33 \\
5 & 450 & 11.65 & 74.52 & 12.98 \\
\hline
\end{tabular}

Table 2. Results of biofuel selectivity with Zn-HZSM-5/ $\gamma$-alumina catalyst composition 1:2

\begin{tabular}{ccccc}
\hline \multirow{2}{*}{ No } & \multicolumn{4}{c}{ Selectivity \% } \\
\cline { 2 - 5 } & Temperature $\left({ }^{\mathbf{C}} \mathbf{C}\right)$ & Biogasoline & Biokerosene & Biodiesel \\
\hline 1 & 350 & 41.22 & 51.94 & 0.86 \\
2 & 375 & 29.30 & 54.33 & 11.94 \\
3 & 400 & 25.80 & 67.39 & 6.22 \\
4 & 425 & 12.68 & 72.50 & 13.51 \\
5 & 450 & 16.22 & 71.46 & 8.94 \\
\hline
\end{tabular}

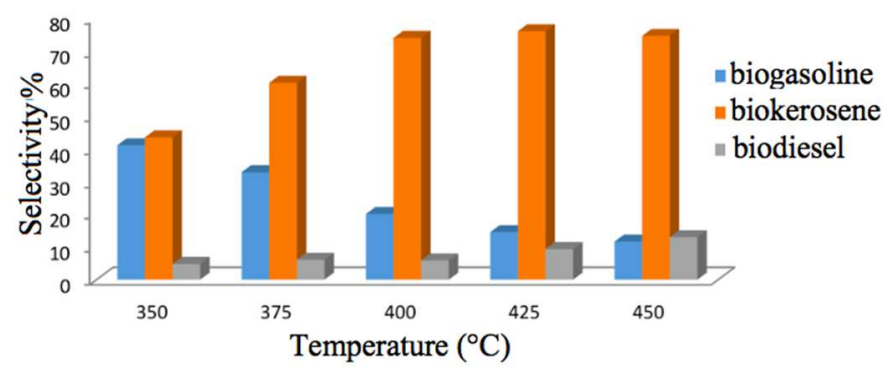

Fig. 3. Effect of Temperature and Zn-HZSM-5/ $/$-alumina catalyst with 1:1 composition on Biofuel selectivity.

Table 1 shows that the higher the temperature of the reaction. the lower the biogasoline selectivity. The results of the biogasoline selectivity reached a maximum value of $41.09 \%$ at a temperature of $350^{\circ} \mathrm{C}$ then continued to descend as the temperature increase. This is caused by at high temperature. there is an increasing gas product due to addition in cracking products. The results of this study were similar to the pattern of production of Cerbera Odollam oil biofuels. The study has shown that the higher the cracking temperature, the lower the biogasoline selectivity [7]. Biokerosene selectivity continues to rise along with the increase of temperature until it reaches a maximum value of $75.94 \%$ at $425^{\circ} \mathrm{C}$ then it decreases at $450^{\circ} \mathrm{C}$. Whilst, biodiesel selectivity continues to raise with a maximum temperature increase of $12.98 \%$ at $450^{\circ} \mathrm{C}$, this was due to an increase in biodiesel and biokerosene selectivity caused by the effect of the Zn-HZSM-5 catalyst.

Figure 3 shows that the temperature of $350^{\circ} \mathrm{C}$ is the most optimal temperature to get biogasoline selectivity. While the optimum biokerosene selectivity is at $425^{\circ} \mathrm{C}$ and the most 
optimal biodiesel selectivity is reached at $450^{\circ} \mathrm{C}$. This shows that one of the factors that has a big influence in the selectivity of biogasoline, biodiesel, and biokerosene is cracking temperature.

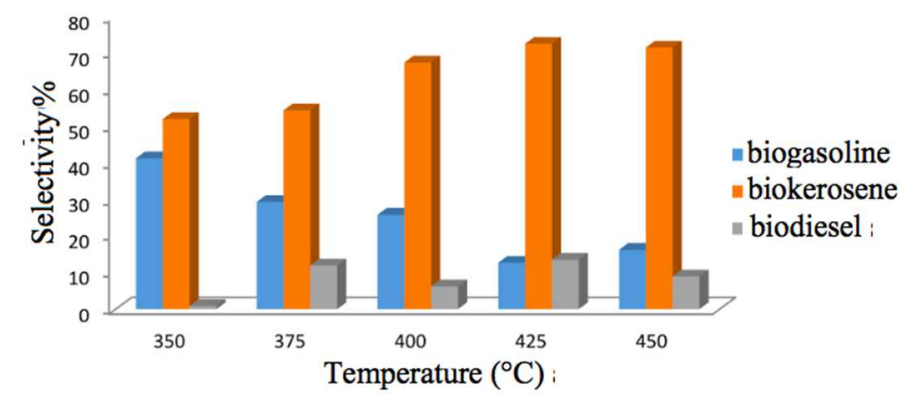

Fig. 4. Effect of Temperature and Zn-HZSM-5/ $/$ - alumina catalyst with 1:2 composition on biofuel selectivity.

Table 2 shows that the higher the reaction temperature, the lower the selectivity of biogasoline. it can be seen that there is a decrease of biogasoline selectivity at $350^{\circ} \mathrm{C}$ to $425^{\circ} \mathrm{C}$ from $47.45 \%$ to $15.19 \%$, followed by escalation at temperatures $450^{\circ} \mathrm{C}$ to $19.26 \%$. Furthermore, with the rise in temperature, the biofuel selectivity begins to decrease because the catalyst activity tends to behave similarly. Seeing the high temperatures, the acidity of the catalyst increases so it is resulting in higher conversion. The product selectivity decreases if the conversion increases [32]. Biokerosene selectivity increased with a rise in temperature at $350^{\circ} \mathrm{C}$ to $450^{\circ} \mathrm{C}$ from $48.94 \%$ to $69.43 \%$. Whereas the selectivity of biodiesel continues to increase along with a maximum temperature rise to $14.75 \%$ at $425^{\circ} \mathrm{C}$ and decrease to $8.30 \%$ at a temperature of $450^{\circ} \mathrm{C}$.

Figure 4 also shows that the optimum biogasoline selectivity is at $350^{\circ} \mathrm{C}$, while the maximum biokerosene and biodiesel selectivity is at $450^{\circ} \mathrm{C}$. Based on the results of the selectivity calculations obtained from all studies with different variables, the maximum biogasoline selectivity of $48.11 \%$ is obtained by the use of Zn-HZSM-5/ $\gamma$-alumina catalysts with a ratio composition of $1: 1$ at $350^{\circ} \mathrm{C}$. The highest biokerosene and biodiesel selectivity is obtained from the use of the same ratio composition of catalyst at $450^{\circ} \mathrm{C}$ at $72.05 \%$ for biokerosene and $12.26 \%$ for biodiesel.

\section{Conclusion}

Studies of Zn-HZSM-5/ $\gamma$-alumina catalyst against RBD stearin cracking have been proven to produce biofuel. Ratio composition of $\mathrm{Zn}-\mathrm{HZSM}-5 / \gamma$-alumina catalyst $(1: 1)$ gives a higher yield than that of Zn-HZSM-5/ $\gamma$-alumina catalyst (1:2). The highest biogasoline selectivity is reached at $48.11 \%$ with a Zn-HZSM-5/ $\gamma$-alumina catalyst (1:1) at a temperature of $350^{\circ} \mathrm{C}$. The highest biokerosene and biodiesel selectivity is reached with $\mathrm{Zn}-\mathrm{HZSM}-5 / \gamma$ alumina catalyst $(1: 1)$ at a temperature of $450^{\circ} \mathrm{C}$ with a yield of $72.05 \%$ for biokerosene and $12.26 \%$ for biodiesel. Zn-HZSM-5/ $\gamma$-alumina catalyst $(1: 1)$ provides two main products that is biogasoline and biokeresene at the various temperature conditions. 


\subsection{Acknowledgment}

This study is funded by DRPM of the Ministry of Research and Technology Republic of Indonesia. The funds are transmitted to LLDIKTI VII Surabaya, so that sincere gratitude to the Chairman of DRPM, LLDIKTI VII, YPTS, and ITATS, also to all stakeholders who have contributed to the accomplishment of this study.

\section{References}

[1] S. Bhatia, A. R. Mohamed, and N. A. A. Shah, "Composites as cracking catalysts in the production of biofuel from palm oil: Deactivation studies," Chem. Eng. J., vol. 155, no. 1-2, pp. 347-354, 2009.

[2] N. Sirajudin, K. Jusoff, S. Yani, L. Ifa, and A. Roesyadi, "Biofuel production from catalytic cracking of palm oil," World Appl. Sci. J., vol. 26, no. 26, pp. 67-71, 2013.

[3] L. Marlinda, "Rekayasa Katalis Double Promotor Berbasis Hierarchical H-ZSM-5 untuk Memproduksi Biofuel dari Minyak Nabati," p. 152, 2017.

[4] A. Roesyadi, D. Hariprajitno, N. Nurjannah, and S. D. Savitri, "HZSM-5 catalyst for cracking palm oil to gasoline: A comparative study with and without impregnation," Bull. Chem. React. Eng. Catal., vol. 7, no. 3, pp. 185-190, 2013.

[5] A. Budianto, D. H. Prajito, K. Budhikarjono, and R. Achmad, "Rekayasa Katalis Komposit Berbasis Zeolit Untuk Proses Cracking Palm Oil Menjadi Biofuel: Pembuatan katalis PDHZSM-5," 2008.

[6] Y. W. Mirzayanti, D. H. Prajitno, and A. Roesyadi, "Catalytic hydrocracking of Kapuk seed oil (Ceiba pentandra) to produce biofuel using Zn-Mo supported HZSM-5 catalyst," IOP Conf. Ser. Earth Environ. Sci., vol. 67, no. 1, 2017.

[7] M. Iqbal, V. Purnomo, and D. H. Prajitno, "Rekayasa Katalis Ni/Zn-HZSM-5 untuk Memproduksi Biofuel dari Minyak Bintaro," J. Tek. Pomits, vol. Vol 3, no. 2, pp. 153-157, 2014.

[8] A. Budianto, D. H. Prajitno, and K. Budhikarjono, "Biofuel production from candlenut oil using catalytic cracking process with Zn/HZSM-5 catalyst," ARPN J. Eng. Appl. Sci., vol. 9, no. 11, pp. 2121-2124, 2014.

[9] S. Sumari, F. Fajaroh, I. Bagus Suryadharma, A. Santoso, and A. Budianto, "Zeolite Impregnated with $\mathrm{Ag}$ as Catalysts for Glycerol Conversion to Ethanol Assisted by Ultrasonic," IOP Conf. Ser. Mater. Sci. Eng., vol. 515, no. 1, 2019.

[10] D. Widiana, H. Saputra, J. T. Kimia, U. Lampung, and B. Lampung, "Sintesis H-ZSM-5 dari Zeolit Alam Lampung ( ZAL ) dengan Sumber Silika Penambah Bagasse Fly Ash ( BFA ) ( Penentuan Rasio TPABr / SiO 2 untuk Memperoleh Produk H-ZSM-5 yang memiliki Kristalinitas Optimum )," vol. 5, no. November, pp. 273-283, 2013.

[11] A. Nurdin, H. Saputra, A. Arfiana, R. Yunilawati, and E. R. Finalis, "Pembuatan Dan Karakterisasi Katalis Zeolit Zsm-5 Untuk Konversi Bioetanol Menjadi Bioetilena," Maj. Ilm. Pengkaj. Ind., vol. 12, no. 2, p. 79, 2018.

[12] S. Sumari, F. Fajaroh, Yahmin, N. Sholihah, A. Santoso, and A. Budianto, "Effect of Temperature Synthesis on Structural Behaviours of NaY Zeolite Using Local Sand as A Silica Source,” IOP Conf. Ser. Mater. Sci. Eng., vol. 515, no. 1, 2019.

[13] A. Budianto, D. H. Prajitno, A. Roesyadi, and K. Budhikarjono, "Hzsm-5 catalyst for cracking palm oil to biodiesel: A comparative study with and without pt and pd impregnation," Sci. Study Res. Chem. Chem. Eng. Biotechnol. Food Ind., vol. 15, no. 1, pp. 81-90, 2014.

[14] R. Tambun, R. P. Saptawaldi, M. A. Nasution, and O. N. Gusti, "Pembuatan Biofuel dari Palm Stearin dengan Proses Perengkahan Katalitik Menggunakan Katalis ZSM-5," J. Rekayasa Kim. Lingkung., vol. 11, no. 1, p. 46, 2016.

[15] R. Rasyid, A. Prihartantyo, M. Mahfud, and A. Roesyadi, "Hydrocracking of Calophyllum 
inophyllum oil with non-sulfide CoMo catalysts," Bull. Chem. React. Eng. Catal., vol. 10, no. 1, pp. 61-69, 2015.

[16] Y. W. Mirzayanti, F. Kurniawansyah, D. H. Prajitno, and A. Roesyadi, "Zn-Mo/HZSM-5 catalyst for gasoil range hydrocarbon production by catalytic hydrocracking of ceiba pentandra oil," Bull. Chem. React. Eng. Catal., vol. 13, no. 1, pp. 136-143, 2018.

[17] E. Y. Emori, F. H. Hirashima, C. H. Zandonai, C. A. Ortiz-Bravo, N. R. C. FernandesMachado, and M. H. N. Olsen-Scaliante, "Catalytic cracking of soybean oil using ZSM5 zeolite," Catal. Today, vol. 279, 2017.

[18] B. Agus, S. Sumari, P. Wahyu Setyo, and Wahyudi, "Production of Various Chemicals from Nyamplung Oil with Catalytic Cracking Process," Indian J. Sci. Technol., vol. 11, no. 37, pp. 17, 2018.

[19] M. A. Hazzamy and I. Zahrina, "Pembuatan Biofuel dari Minyak Goreng Bekas Melalui Proses Catalytic Cracking dengan Katalis Fly Ash," 2013.

[20] E. Buzetzki, K. Sidorová, Z. Cvengrošová, A. Kaszonyi, and J. Cvengroš, "The influence of zeolite catalysts on the products of rapeseed oil cracking," Fuel Process. Technol., vol. 92, no. 8, pp. 1623-1631, 2011.

[21] S. Sumari, F. Fajaroh, I. Bagus Suryadharma, A. Santoso, and A. Budianto, "Zeolite Impregnated with Ag as Catalysts for Glycerol Conversion to Ethanol Assisted by Ultrasonic," in IOP Conference Series: Materials Science and Engineering, 2019, vol. 515, no. 1.

[22] A. Budianto, S. Sumari, and K. Udyani, "Biofuel production from nyamplung oil using catalytic cracking process with Zn-HZSM-5/ $\gamma$ alumina catalyst," ARPN J. Eng. Appl. Sci., vol. 10, no. 22, pp. 10317-10323, 2015.

[23] A. Budianto, W. S. Pambudi, S. Sumari, and A. Yulianto, "PID control design for biofuel furnace using arduino," Telkomnika (Telecommunication Comput. Electron. Control., vol. 16, no. $6,2018$.

[24] M. Y. Annur, Y. Yelmida, and Z. Zultiniar, "Perengkahan Katalitik Palm Fatty Acid Distillate Menjadi Biofuel Menggunakan katalis Natrium Karbonat dengan variasi Temperatur dan Konsentrasi katalis Natrium Karbonat," J. Online Mhs. Fak. Tek. Univ. Riau, vol. 2, no. 1, pp. $1-6,2015$.

[25] B. Blesvid, Yelmida, and Zultinar, "Perengkahan Katalitik Palm Fatty Acid Distillate ( PFAD ) Menjadi Biofuel Dengan Katalis Abu TKS Variasi Temperatur dan Berat Katalis," J. Rekayasa Kim. dan Lingkung., vol. vol 10 No, pp. 1-6, 2013.

[26] D. S. Hajj, D. A. Rp, and A. Budianto, "Pembuatan Biofuel dengan Proses Perengkahan dari Palm Fatty Acid Distillate ( PFAD ) Menggunakan Katalis CaO," pp. 607-614.

[27] A. Budianto, S. Sumari, W. S. Pambudi, and N. Andriani, "Uji Coba Produksi Biofuel dari RBD Stearin dalam Reaktor Fixed Bed dengan Metode Cracking," in Prosiding Seminar Nasional Sains dan Teknologi Terapan, 2019, pp. 735-740.

[28] N. Yuda Wardana, N. Caroko, and T. Thoharudin, "Pirolisis Lambat Campuran Cangkang Sawit Dan Plastik Dengan Katalis Zeolit Alam,” Teknoin, vol. 22, no. 5, pp. 361-366, 2016.

[29] A. Budianto, "Pirolisiss Botol Plastik Bekas Minuman Air Mnieral Jenis Pet Menjadi Fuel," Semin. Nas. Sains dan Teknol. Terap. V, pp. 201-206, 2017.

[30] E. Kozliak, R. Mota, D. Rodriguez, P. Overby, A. Kubátová, D. Stahl, V. Niri, G. Ogden, and W. Seames, "Non-catalytic cracking of jojoba oil to produce fuel and chemical by-products," Ind. Crops Prod., vol. 43, no. 1, pp. 386-392, 2013.

[31] D. Ortega, L. Noreña, J. Aguilar, I. Hernández, and V. Ramírez, "Recycling of plastic materials employing zeolite and MCM-41 materials," Rev. Mex. Ing. Quimica, vol. 5, no. 3, pp. 189-195, 2006.

[32] A. Santoso, Sumari, R. Joharmawan, and L. B. Hutami, "Catalytic cracking of waste frying oil using Ni-Fe/activated zeolite catalyst as a source of renewable energy," IOP Conf. Ser. Mater. Sci. Eng., vol. 509, no. 1, 2019. 